\title{
Fungicide Sensitivity Monitoring of Alternaria spp. Causing Leaf Spot of Sugarbeet (Beta vulgaris) in the Upper Great Lakes
}

\author{
N. Rosenzweig, ${ }^{1 \dagger}$ L. E. Hanson, ${ }^{2}$ S. Mambetova, ${ }^{1}$ Q. W. Jiang, ${ }^{1}$ C. Guza, ${ }^{3}$ J. Stewart, ${ }^{3}$ and P. Somohano ${ }^{1}$ \\ ${ }^{1}$ Department of Plant, Soil, and Microbial Sciences, Michigan State University, East Lansing, MI 48824 \\ ${ }^{2}$ U.S. Department of Agriculture Agricultural Research Service, East Lansing, MI 48824 \\ ${ }^{3}$ Michigan Sugar Company, Bay City, MI 48706
}

\begin{abstract}
Alternaria leaf spot (ALS), caused by Alternaria spp., can occur wherever sugarbeet is grown. Infection by Alternaria spp. and disease management has historically been considered a minor issue in sugarbeet production in the United States. An increase of both incidence and severity in 2016 of ALS high enough to cause yield loss has been observed in Michigan. With a renewed need to consider potential management of this disease, the sensitivity was determined for populations of Alternaria spp. to three classes of fungicides currently labeled for management of leaf spot on sugarbeet, including demethylase inhibitor (DMI), quinone outside inhibitor (QoI), and organo-tin fungicides. Leaves with symptoms of ALS were sampled from sugarbeet fields in east-central Michigan and southwestern Ontario, Canada. Monoconidial isolates were obtained to determine sensitivity to each fungicide class above. A spiral gradient

dilution method was used to estimate the fungicide effective concentration (in milligrams per liter) that caused a 50\% inhibition of fungal growth in vitro for all isolates. Significant temporal shifts were detected in the frequencies of sensitivity phenotypes to DMI and QoI but not organo-tin fungicides from 2016 through 2017. Individual isolates of Alternaria spp. were recovered with cross-resistance to DMI and multiple resistance to DMI, QoI, and triphenyltin hydroxide fungicides. To our knowledge, this is the first report of a fungus other than Cercospora beticola with resistance to organo-tin fungicides. Fungicide sensitivity monitoring indicates that an effective integrated disease management approach combining fungicide efficacy trials and monitoring pathogen biology is essential for developing effective resistance management recommendations.
\end{abstract}

Alternaria leaf spot (ALS), caused by Alternaria spp. in the A. alternata and $A$. brassicae species groups, is an annually occurring disease wherever sugarbeet is grown, owing to the cosmopolitan nature of Alternaria spp. (Franc 2009). Infection by Alternaria spp. causes conspicuous necrotic spots on all aerial parts of the sugarbeet plant (Franc 2009). Subsequently, leaf spots expand and form lesions that may become uniform, concentric, and/or zonate (Franc 2009). Foliar infection by Alternaria spp. results in the reduction of photosynthetic area, accelerated senescence, and defoliation (Franc 2009). Infection by Alternaria spp. is commonly observed in association with Beet western yellow virus (BWYV) and other stresses that cause yellowing of the beet foliage (Franc 2009). ALS also can potentially affect sugar yield by increasing sodium content in the root (Russell 1965).

Infection by Alternaria spp. and disease management has historically been considered a minor issue in sugarbeet production in North America, owing to its opportunistic or secondary nature (Franc 2009; Russell 1965) and because damage from ALS usually does not significantly affect crop yield (Franc 2009). Additionally, the presence and severity of ALS has largely been attributed to a predisposition in

${ }^{\dagger}$ Corresponding author: N. Rosenzweig; rosenzw4@msu.edu

Funding: This project was partially supported by the Michigan Sugar Company Research \& Education Advisory Council and the Michigan State University Project GREEEN (Generating Research and Extension to Meet Economic and Environmental Needs). Mention of trade names or commercial products in this publication is solely for the purpose of providing specific information and does not imply recommendation or endorsement by the United States Department of Agriculture.

*The $\boldsymbol{e}$-Xtra logo stands for "electronic extra" and indicates that four supplementary tables are published online.

The author(s) declare no conflict of interest.

Accepted for publication 30 March 2019

C 2019 The American Phytopathological Society the sugarbeet crop as a result other biotic and abiotic stressors (Franc 2009). In contrast, ALS is a major concern in some sugarbeet production areas outside the United States, where the disease directly results in significant reductions in sugar yield (Abbas et al. 2014; Özgönen and Kılıç 2009). During the 2015 growing season, an increased incidence and severity of ALS was observed in Michigan sugarbeet production (Rosenzweig et al. 2017). Disease severity was observed at levels that previously were reported to have the potential to cause yield loss attributable to defoliation (Russell 1965). The increase in disease pressure of ALS was caused by conducive environmental conditions coupled with a significant percentage of sugarbeet production acreage planted with seed from ALS susceptible germplasm. Moreover, the levels of disease pressure in some growers' fields were high enough to raise potential concerns for sugarbeet production in the region. Little is known about the epidemiology of ALS related to Cercospora leaf spot (CLS) coinfection on sugarbeet. In the case of coinfection of sugarbeet by BWYV and ALS, an increase in susceptibility results from weakening of the whole plant (Russell 1965). The primary points of entry are yellow senescing leaves (Rotem 1994). Alternaria spp. have been shown to cause disease on both seed and seedlings of sugarbeet (Neergaard 1945). Additionally, Alternaria spp. can infect the inflorescence from which it passes to seeds and can lead to damping off of seedlings (Neergaard 1945). Because ALS has not been a concern in the United States, little is known about the interaction with varieties of beet host (Franc 2009) or sensitivity to currently available fungicides used in chemical management programs for foliar diseases. Conducive weather conditions for ALS are reported to include high humidity and low to moderate temperatures (Franc 2009). A. brassicae was reported to cause disease primarily at temperatures between 7 and $10^{\circ} \mathrm{C}$, with no disease development above $16^{\circ} \mathrm{C}$ (McFarlane et al. 1954). Isolates in the $A$. alternata species group can be active at a wider temperature range but still have optimum development at cool temperatures, although specifics for beet are lacking. The optimum temperature for growth is around $25^{\circ} \mathrm{C}$ for A. alternata (syn. A. tenuis), with growth decreasing rapidly as temperature increases (Hasija 1970). ALS is most commonly seen in the Michigan growing region in early summer, decreases as summer temperatures rise, and increases again in the fall (unpublished data). 
Initial monitoring in 2016 of isolates of Alternaria spp. with high levels of insensitivity to many classes of fungicides were concomitantly recovered with Cercospora beticola causing CLS, the major foliar pathogen in the region from commercial production areas in Michigan and Ontario, Canada. Isolates of Alternaria spp. were tolerant to the quinone outside inhibitor (QoI), demethylase inhibitor (DMI), and triphenyltin hydroxide fungicides (Rosenzweig et al. 2017). Moreover, ALS is being increasingly observed in association with beets that also have lesions from $C$. beticola isolates tolerant to benzimidazole, QoI, and DMI fungicides (difenoconazole, tetraconazole, prothioconazole, and flutriafol). Resistance to these chemistries has been found in C. beticola in the region (Kirk et al. 2012; Rosenzweig et al. 2015; Trueman et al. 2013, 2017). Additionally, in 2015 and 2016, Alternaria spp. with insensitivity to the QoI fungicide pyraclostrobin (Fungicide Resistance Action Committee [FRAC] group 11) were recovered from fields in Michigan (Rosenzweig et al. 2017). Monoconidial isolates of Alternaria spp. recovered from individual ALS lesions were identified to species based on conidial morphology (Simmons 2007) and molecular-based methods (Woudenberg et al. 2013) by DNA sequencing (Rosenzweig et al. 2017). Sequence analysis revealed that intermediate and resistant isolates contained a substitution of G143A in the cytb gene (Rosenzweig et al. 2017), which confers QoI resistance in A. alternata (Grasso et al. 2006).

These results indicate the potential for the development of resistance in Alternaria isolates found in the region to currently used fungicides for leaf spot management. Management has been aimed at CLS but also may have indirectly impacted ALS in the past. Similar results have been reported in Alternaria spp. found on other crops with resistance to several different fungicide classes and the genetic mechanism is known (Avenot and Michailides 2007; Dewdney and Vega 2012; Ma and Michailides 2004a; Ma et al. 2003; Malandrakis et al. 2015). Typically, tolerance to QoIs and benzimidazole fungicides is attributable to mutations in the cytochrome $b$ (AvilaAdame et al. 2003; Bartlett et al. 2002; Chin et al. 2001; Ishii et al. 2001; Küng Färber et al. 2002; Olaya et al. 2003; Pasche et al. 2005; Rosenzweig et al. 2008a, b, 2017) and $\beta$-tubulin genes (Cooley and Caten 1993; Davidse and Flach 1977; Jung et al. 1992; Reijo et al. 1994) respectively. These mutations cause codon substitutions and result in amino acid changes that reduce the binding specificity of the given fungicides at the target site.

Management problems related to application timing of fungicides and development of insensitivity to fungicides in pathogen populations causing leaf spot of sugarbeet (e.g., CLS) have impacted sugarbeet production regionally (Rosenzweig et al. 2015). The limited availability of effective active ingredients and significant economic cost necessitates the application of products with similar modes of actions in the same fungicide class and a reduction in total applications over the growing season to manage foliar diseases of sugarbeet in the Upper Great Lakes Region. Because of the potentially wide host range of Alternaria spp. causing ALS (Franc 2009), these pathogens have the potential to be exposed to these same fungicides even when sugarbeet is not present or planted. In addition, management can be hampered because some of the fungicides may not even be labeled for ALS. With the increasing incidence and potential for losses in the region with this pathogen, fungicide resistance monitoring in sugarbeet production areas in Michigan and Ontario is warranted.

Sensitivity monitoring is essential for the development of fungicide resistance management recommendations (Bauske et al. 2018; Thomas et al. 2012). Moreover, information on the population biology of plant pathogens related to fungicide sensitivity is important to evaluate the efficacy of available fungicides (Bauske et al. 2018) as well as the potential impact of management on long-term utility of various compounds (e.g., recurrence of tin sensitivity). The objective of this study was to establish a monitoring program by (i) collecting ALS-infected sugarbeet leaves from commercial production fields in eastern Michigan and western Ontario, Canada; (ii) determining the sensitivity of the recovered populations of Alternaria spp. to three classes of fungicides, including DMI fungicides (difenoconazole, fenbuconazole, flutriafol, prothioconazole, and tetraconazole), a QoI fungicide (pyraclostrobin), and an organo-tin (triphenyl tin
$\mathrm{OH}$ ); and (iii) determining temporally the frequency of fungicide sensitivity phenotypes from 2016 through 2017 across the sugarbeet production area of the Upper Great Lakes.

\section{Materials and Methods}

Isolates and sampling. Isolates of Alternaria spp. were collected from leaves with symptoms of ALS sampled from sugarbeet fields in east-central Michigan during September and October in 2016 (60 fields) and 2017 (82 fields). Samples of up to 20 leaves from throughout a selection of sugarbeet production fields in Michigan and Ontario were used in sensitivity testing. Isolates of Alternaria spp. were recovered from infected leaf tissue from multiple field locations using standard methods (Rosenzweig et al. 2008a, b). Monoconidial isolates from individual ALS lesions were obtained to determine sensitivity to each fungicide described below. From each sugarbeet leaf, representative lesions were cut with a number 5 cork-borer; the lesions were chosen as being of similar sizes and in similar stages of sporulation and surface disinfested with $0.6 \% \mathrm{NaClO}$. All single lesion leaf disks derived from a particular sampling site were placed onto $1.5 \%$ water agar media amended with streptomycin $(50 \mathrm{mg} /$ liter) and $\mathrm{CaCO}_{3}(0.15 \% \mathrm{wt} / \mathrm{vol})$ for sporulation induction and positive identification. One conidium of Alternaria sp. from individual lesions was transferred to clarified V-8 (CV8) media (Miller 1955) amended with streptomycin and $\mathrm{CaCO}_{3}$ for subsequent fungicide sensitivity assays and long-term storage.

In vitro fungicide sensitivity of Alternaria spp. by dilution gradient. Active ingredients of difenoconazole (Inspire; FRAC group 3), fenbuconazole (Enable; FRAC group 3), flutriafol (Topguard; FRAC group 3), prothioconazole (Proline; FRAC group 3), tetraconazole (Eminent125 SL; FRAC group 3), pyraclostrobin (Headline 2.08SC; FRAC group 11), and triphenyl tin OH (Super Tin 80WP; FRAC group 30) were prepared as stock solutions of $10,000 \mathrm{mg} /$ liter of each fungicide by dissolving technical-grade fungicides in an appropriate sterile solvent (ethanol or acetone). Previous studies determined that salicylhydroxamic acid (SHAM) was toxic to germinating conidia for isolates tested; thus, the effective concentration in inhibiting growth by $50 \%\left(\mathrm{EC}_{50}\right)$ values for pyraclostrobin were based on assays from fungicide-only amended agar (Rosenzweig et al. 2017). Subsequently, $50 \mathrm{ml}$ of fungicideamended and nonamended CV8 agar was poured into each dish, to form a layer of agar with a constant volume; thus when a stock solution is added to the agar, it results in a gradient from 0 to $1,000 \mathrm{mg} /$ liter across the agar surface. The $\mathrm{EC}_{50}$ value was determined for individual isolates. A spiral gradient plater method was used to determine the $\mathrm{EC}_{50}$ value (Förster et al. 2004). The spiral gradient method was selected based on cost, efficiency, and relative accuracy. Conidial suspensions were prepared by flooding 2-week-old pure Alternaria spp. cultures grown on Petri dishes with $1 \mathrm{ml}$ of distilled water and scraping the conidia free from the surface with a rubber policeman. An aliquot of the conidial suspension $(10 \mu \mathrm{l})$ was spread across the fungicide gradient plate from the edge to the center. Isolates were incubated for 7 days at $24^{\circ} \mathrm{C}$ in the dark (three replications). The point coordinates at which the colony growth began and ended was recorded and entered into the ECX package (Torres-Londoño et al. 2016) in the RStudio software program (Boston, MA), and the $\mathrm{EC}_{50}$ value for each isolate and fungicide was calculated.

Data analysis. Categorical data were analyzed using a log-linear analysis approach based on collection year. The CATMOD procedure was employed using SAS software (Statistical Analysis System, version 9.3; SAS Institute) with log link. Additionally, PROC CATMOD provided maximum-likelihood estimates for the main effects of year.

\section{Results}

Determination of temporal shifts in fungicide sensitivity of Alternaria spp. The sensitivity of the recovered populations of Alternaria spp. was determined for five DMIs as well as one QoI and one organo-tin fungicide. A total of 143, 140, 131, 143, 144, 131, and 147 isolates of Alternaria spp. were screened against difenoconazole, fenbuconazole, flutriafol, prothioconazole, tetraconazole, 
pyraclostrobin, and triphenyl tin $\mathrm{OH}$ fungicides, respectively, in 2016 (Table 1). A total of 236, 243, 250, 247, 240, 241, and 249 isolates of Alternaria spp. were screened against difenoconazole, fenbuconazole, flutriafol, prothioconazole, tetraconazole, pyraclostrobin, and triphenyl tin $\mathrm{OH}$ fungicides, respectively, in 2017 (Table 1).

For difenoconazole, the mean $\mathrm{EC}_{50}$ values were 3.8 and $5.7 \mathrm{mg} /$ liter in 2016 and 2017, respectively (Table 1). The mean EC $_{50}$ values ranged from 0.6 to $7.2 \mathrm{mg} /$ liter among counties in 2016 (Supplementary Table S1) and from 0.7 to $12.9 \mathrm{mg} /$ liter among counties and Ontario, respectively, in 2017 (Supplementary Table S2).

For fenbuconazole, the mean $\mathrm{EC}_{50}$ values were 79.3 and $86.8 \mathrm{mg} / \mathrm{liter}$ in 2016 and 2017, respectively (Table 1). The mean $\mathrm{EC}_{50}$ values ranged from 3.7 to $98.5 \mathrm{mg} /$ liter among counties in 2016 and from 62.0 to $133.6 \mathrm{mg} /$ liter among counties and Ontario, respectively, in 2017.

For flutriafol, the mean $\mathrm{EC}_{50}$ values were 52.7 and $73.5 \mathrm{mg} / \mathrm{liter}$ in 2016 and 2017, respectively (Table 1). The mean $\mathrm{EC}_{50}$ values ranged from 0.8 to $110.0 \mathrm{mg} / \mathrm{liter}$ among counties in 2016 and from ranged from 8.6 to 95.1 among counties and Ontario, respectively, in 2017.

For prothioconazole, the mean $\mathrm{EC}_{50}$ values were 71.7 and $53.5 \mathrm{mg} / \mathrm{liter}$ in 2016 and 2017, respectively (Table 1). The mean $\mathrm{EC}_{50}$ values ranged from 0.7 to $106.3 \mathrm{mg} / \mathrm{liter}$ among counties in 2016 and from 24.9 to $86.1 \mathrm{mg} / \mathrm{liter}$ among counties and Ontario, respectively, in 2017.

For tetraconazole, the mean $\mathrm{EC}_{50}$ values were 102.1 and $76.9 \mathrm{mg} /$ liter in 2016 and 2017, respectively (Table 1). The mean $\mathrm{EC}_{50}$ values ranged from 42.0 to $136.5 \mathrm{mg} /$ liter among counties in 2016 and from 38.9 to $116.4 \mathrm{mg} / \mathrm{liter}$ among counties and Ontario, respectively, in 2017.

For pyraclostrobin, the mean $\mathrm{EC}_{50}$ values were 59.0 and $91.7 \mathrm{mg} /$ liter in 2016 and 2017, respectively (Table 1). The mean $\mathrm{EC}_{50}$ values ranged from 0.6 to $128.0 \mathrm{mg} /$ liter among counties in 2016 (Supplementary Table S3) and from 35.9 to $128.0 \mathrm{mg} /$ liter among counties and Ontario, respectively, in 2017 (Supplementary Table S4).

For triphenyl tin $\mathrm{OH}$, the mean $\mathrm{EC}_{50}$ values were 16.5 and $39.0 \mathrm{mg} /$ liter in 2016 and 2017, respectively (Table 1). The mean $\mathrm{EC}_{50}$ values ranged from 0.7 to $63.3 \mathrm{mg} / \mathrm{liter}$ among counties in 2016 and from 33.1 to $52.6 \mathrm{mg} /$ liter among counties and Ontario, respectively, in 2017.

Determination of temporal frequency distribution of fungicide sensitivity in Alternaria spp. For difenoconazole, the relative frequency of isolates with $\mathrm{EC}_{50}$ values of $<1,1$ to 5,5 to 10 , and 10 to $50 \mathrm{mg} / \mathrm{liter}$ was $50.3,32.2,11.9$, and $5.6 \%$, respectively, in 2016 (Fig. 1) compared with the relative frequency of isolates with $\mathrm{EC}_{50}$ values in the same classes of 50.8, 33.9, 5.9, 5.5, 0.8, and $1.7 \%$ respectively, in 2017 (Fig. 1). The distribution of isolates in these sensitivity classes to the other fungicides was determined over the 2 years of monitoring (Figs. 2, 3, 4, 5, 6, and 7). Of particular note are those for tetraconazole, which showed a different pattern in the relative frequency of isolates with $\mathrm{EC}_{50}$ values of 1 to 5,5 to 10 , 10 to 50,50 to 100 , and $>100 \mathrm{mg} /$ liter of $1.4,0.7,22.9,9.7$, and $65.3 \%$ in 2016 and $0.4,3.8,7.9,27.9,17.1$, and $42.5 \%$ in 2017 , respectively (Fig. 5).

Temporal comparison of population resistance factors in Alternaria spp. The monitoring program for Alternaria spp. was initiated in the last three growing season and could not be characterized as baseline because of the pathogen's wide host range isolates (no exposure). Therefore, isolates characterized as sensitive were based on previously published data on mean sensitivity of A. alternata to the studied fungicides (Avenot et al. 2016; Dewdney and Vega 2012; Iacomi-Vasilescu et al. 2004). Isolates of Alternaria spp. were categorized phenotypically into five sensitivity categories based on mean $\mathrm{EC}_{50}$ values as follows: $\mathrm{EC}_{50}<1 \mathrm{mg} /$ liter, sensitive $(\mathrm{S}) \mathrm{EC}_{50}$ of 1 to $10 \mathrm{mg} /$ liter, reduced sensitive (RS); $\mathrm{EC}_{50}$ of 10 to $50 \mathrm{mg} / \mathrm{liter}$, moderately insensitive (MI); $\mathrm{EC}_{50}$ of 50 to $100 \mathrm{mg} / \mathrm{liter}$, insensitive (I); and $\mathrm{EC}_{50}>100 \mathrm{mg} / \mathrm{liter}$, resistant $(\mathrm{R})$. The resistance factor (RF), based on $\mathrm{EC}_{50}$ values, was calculated for populations of Alternaria

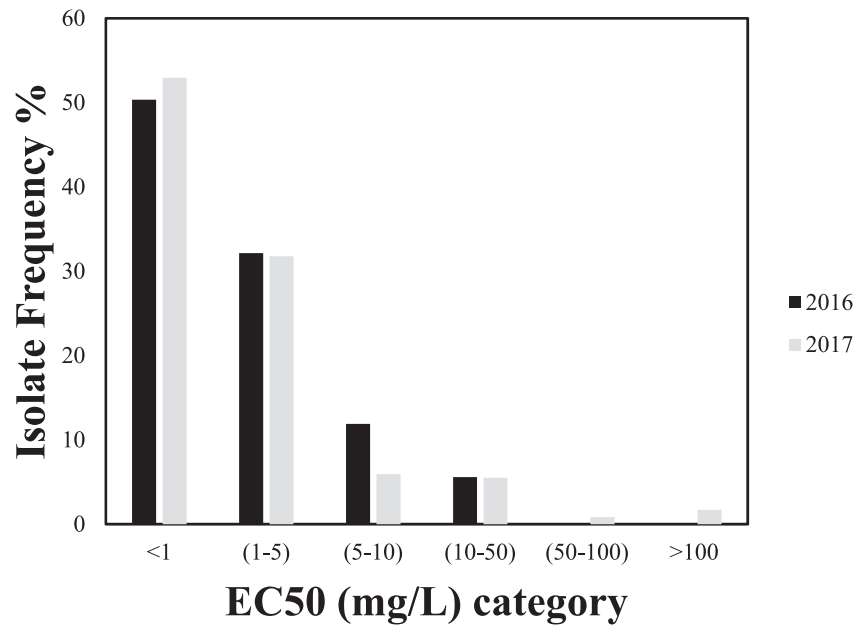

Fig. 1. Frequency distributions of in vitro sensitivity to difenoconazole of Alternaria spp. isolates recovered in Michigan from sugarbeet leaves collected from 2016 and 2017. Sensitivity expressed as $50 \%$ inhibition of fungal growth $\left(E C_{50}\right)$ in vitro, fungicide concentration estimate determined by the spiral gradient dilution method.

Table 1. Comparison of mean effective concentration for reduction in growth by $50 \%\left(\mathrm{EC}_{50}\right)$ for isolates of Alternaria spp. from sugarbeet in Michigan to seven fungicides in 2016 and 2017

\begin{tabular}{|c|c|c|c|c|c|}
\hline \multirow[b]{2}{*}{ Active ingredient } & \multirow[b]{2}{*}{ FRAC code ${ }^{a}$} & \multirow[b]{2}{*}{ Total no. of isolates } & \multicolumn{3}{|c|}{$\mathrm{EC}_{50}(\mathrm{mg} / \mathrm{liter})^{\mathrm{b}}$} \\
\hline & & & Mean \pm S.E.M. & Minimum & Maximum \\
\hline \multicolumn{6}{|l|}{2016} \\
\hline Difenoconazole & 3 & 143 & $3.8 \pm 0.5$ & 0.6 & 37.4 \\
\hline Fenbuconazole & 3 & 140 & $79.3 \pm 4.6$ & 0.7 & 133.6 \\
\hline Flutriafol & 3 & 131 & $52.7 \pm 4.4$ & 0.8 & 137.8 \\
\hline Prothioconazole & 3 & 143 & $71.7 \pm 4.8$ & 0.7 & 132.7 \\
\hline Tetraconazole & 3 & 144 & $102.1 \pm 3.6$ & 4.0 & 136.5 \\
\hline Pyraclostrobin & 11 & 131 & $59.0 \pm 4.4$ & 0.6 & 128.0 \\
\hline Triphenyl tin $\mathrm{OH}$ & 30 & 147 & $16.5 \pm 0.9$ & 0.7 & 63.3 \\
\hline \multicolumn{6}{|l|}{2017} \\
\hline Difenoconazole & 3 & 236 & $5.7 \pm 1.2$ & 0.6 & 126.2 \\
\hline Fenbuconazole & 3 & 243 & $86.8 \pm 3.4$ & 0.7 & 133.6 \\
\hline Flutriafol & 3 & 250 & $73.5 \pm 3.6$ & 0.8 & 137.8 \\
\hline Prothioconazole & 3 & 247 & $53.5 \pm 3.5$ & 0.7 & 132.7 \\
\hline Tetraconazole & 3 & 240 & $76.9 \pm 3.4$ & 0.8 & 136.5 \\
\hline Pyraclostrobin & 11 & 241 & $91.7 \pm 3.3$ & 0.6 & 128.0 \\
\hline Triphenyl tin $\mathrm{OH}$ & 30 & 249 & $39.0 \pm 1.5$ & 0.7 & 130.2 \\
\hline
\end{tabular}

${ }^{a}$ FRAC $=$ Fungicide Resistance Action Committee group name based on chemical relatedness and mode of action.

${ }^{\mathrm{b}} \mathrm{EC}_{50}$ values determined for two replications based on mean effective concentration for reduction in growth by $50 \%$ using a spiral gradient dilution method. 


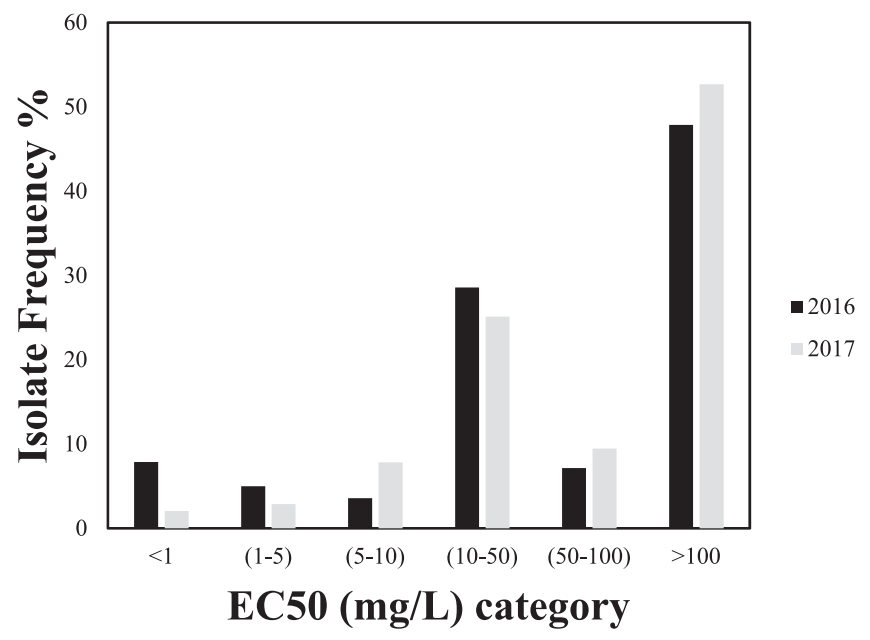

Fig. 2. Frequency distributions of in vitro sensitivity to fenbuconazole of Alternaria spp. isolates recovered in Michigan from sugarbeet leaves collected from 2016 and 2017. Sensitivity expressed as $50 \%$ inhibition of fungal growth $\left(\mathrm{EC}_{50}\right)$ in vitro, fungicide concentration estimate determined by the spiral gradient dilution method.

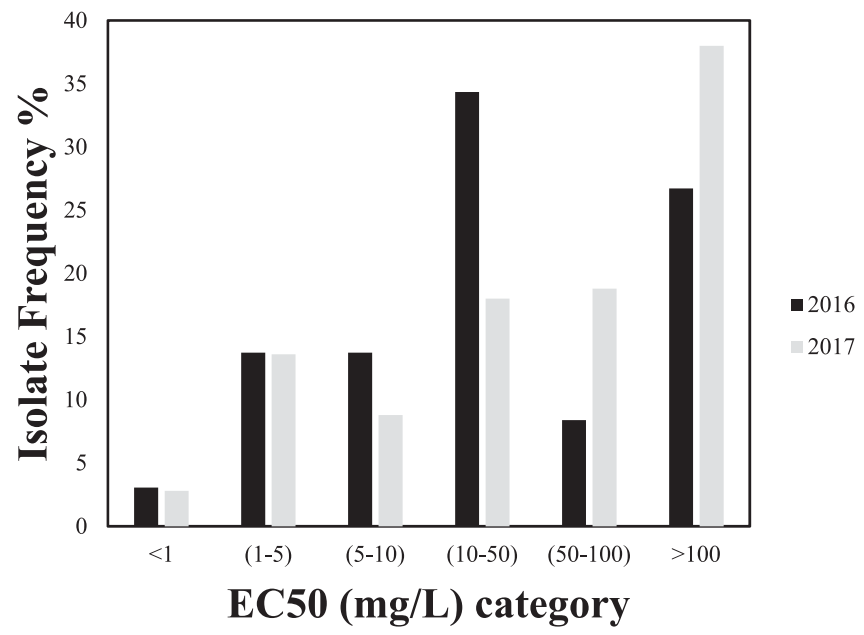

Fig. 3. Frequency distributions of in vitro sensitivity to flutriafol of Alternaria spp. isolates recovered in Michigan from sugarbeet leaves collected from 2016 and 2017. Sensitivity expressed as $50 \%$ inhibition of fungal growth $\left(E_{50}\right)$ in vitro, fungicide concentration estimate determined by the spiral gradient dilution method.

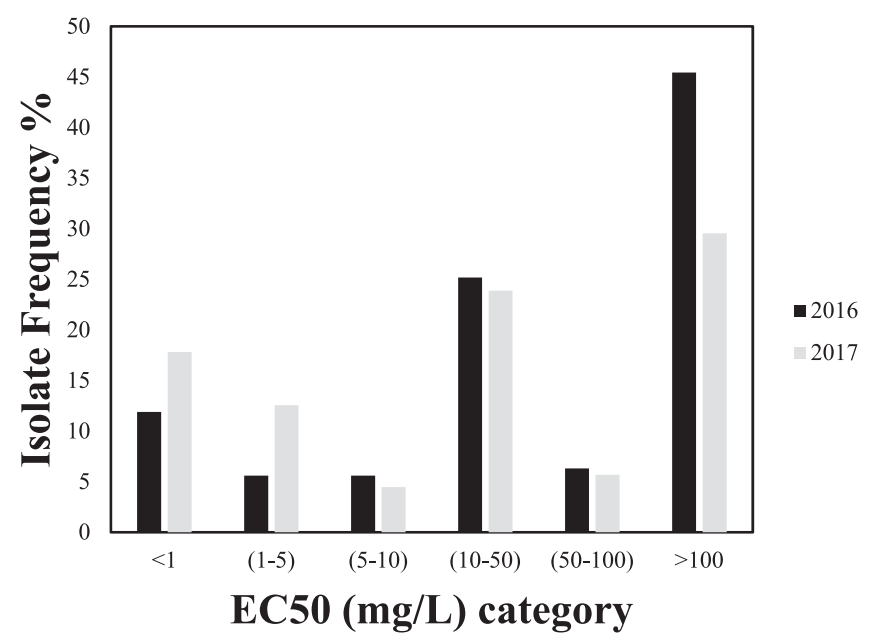

Fig. 4. Frequency distributions of in vitro sensitivity to prothioconazole of Alternaria spp. isolates recovered in Michigan from sugarbeet leaves collected from 2016 and 2017. Sensitivity expressed as $50 \%$ inhibition of fungal growth $\left(E_{50}\right)$ in vitro, fungicide concentration estimate determined by the spiral gradient dilution method.

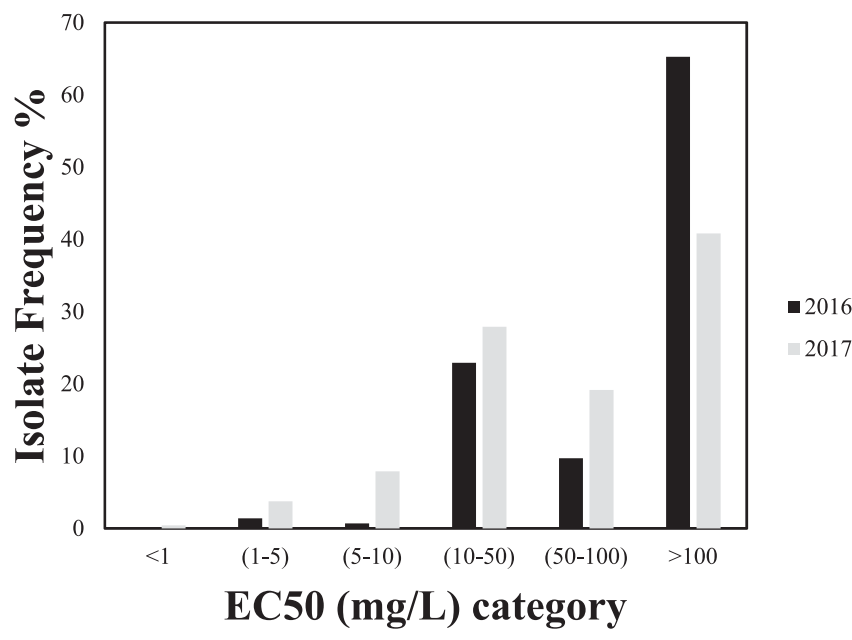

Fig. 5. Frequency distributions of in vitro sensitivity to tetraconazole of Alternaria spp. isolates recovered in Michigan from sugarbeet leaves collected from 2016 and 2017. Sensitivity expressed as $50 \%$ inhibition of fungal growth $\left(E_{50}\right)$ in vitro, fungicide concentration estimate determined by the spiral gradient dilution method.

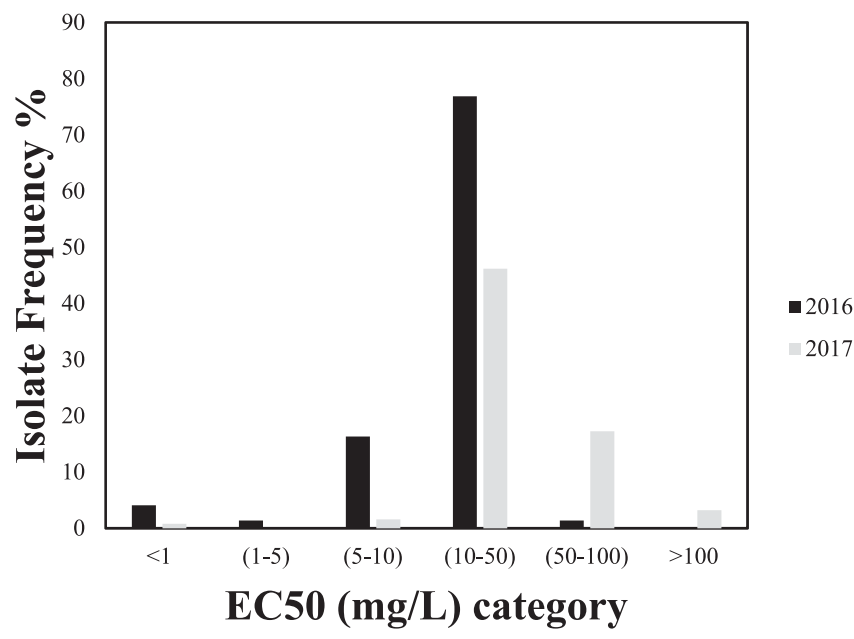

Fig. 6. Frequency distributions of in vitro sensitivity to pyraclostrobin of Alternaria spp. isolates recovered in Michigan from sugarbeet leaves collected from 2016 and 2017. Sensitivity expressed as $50 \%$ inhibition of fungal growth $\left(E_{50}\right)$ in vitro, fungicide concentration estimate determined by the spiral gradient dilution method.

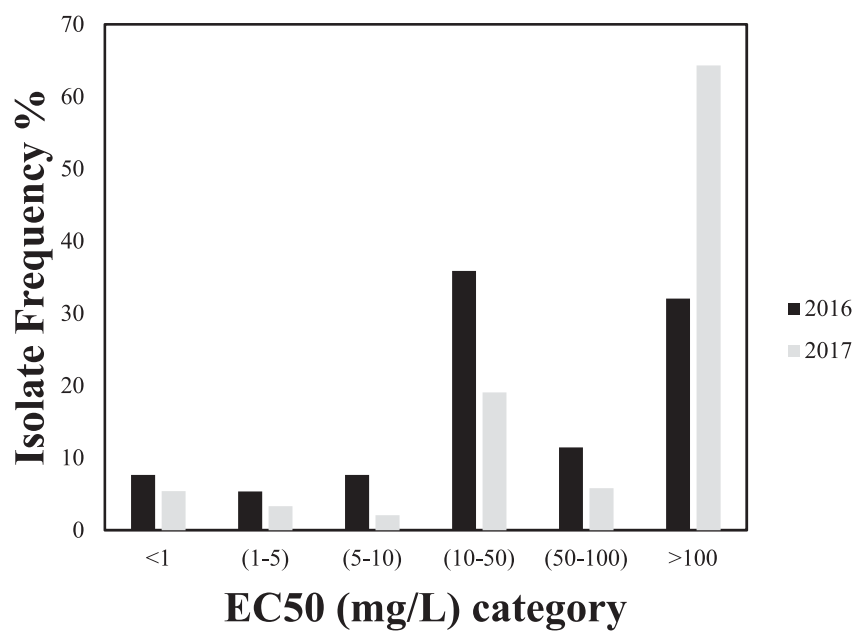

Fig. 7. Frequency distributions of in vitro sensitivity to triphenyl tin $\mathrm{OH}$ of Alternaria spp. isolates recovered in Michigan from sugarbeet leaves collected from 2016-2017. Sensitivity expressed as $50 \%$ inhibition of fungal growth $\left(\mathrm{EC}_{50}\right)$ in vitro, fungicide concentration estimate determined by the spiral gradient dilution method. 
spp. characterized as $\mathrm{RS}\left(\mathrm{EC}_{50 \mathrm{RS}} / \mathrm{EC}_{50 \mathrm{~S}}\right)$, MI $\left(\mathrm{EC}_{50 \mathrm{MI}} / \mathrm{EC}_{50 \mathrm{~S}}\right)$, I $\left(\mathrm{EC}_{50 \mathrm{I}} / \mathrm{EC}_{50 \mathrm{~S}}\right)$, and $\mathrm{R}\left(\mathrm{EC}_{50 \mathrm{R}} / \mathrm{EC}_{50 \mathrm{~S}}\right)$. The $\mathrm{RF}$ was calculated for populations of Alternaria spp. sensitive to all seven fungicides tested (Tables 2 and 3).

For difenoconazole, the RFs of populations of RS and MI were 6.3 and 35.3, respectively, in 2016 (Table 2), whereas the RFs of populations of RS, MI, I, and R were 4.8, 32.6, 105.4, and 143.4, respectively, in 2017. Similar patterns were seen for other DMI fungicides (Table 2).

For pyraclostrobin, the RFs of populations of RS, MI, I, and R were $8.8,46.2,108.4$, and 202.9 in 2016 (Table 3). The RFs of populations of RS, MI, I, and R were 6.9, 37.9, 115.7, and 201.4, respectively, in 2017 (Table 3).

For triphenyl tin $\mathrm{OH}$, the RFs of populations of RS, MI, and I were 12.4, 28.4, and 86.7 in 2016 (Table 3). The RFs of populations of RS, MI, I, and $\mathrm{R}$ were 10.1, 46.2, 98.6, and 185.7, respectively, in 2017 (Table 3).

Determining temporal frequency distribution of Alternaria spp. fungicide sensitivity phenotypes. For difenoconazole, loglinear analysis determined that collection year had a significant effect on the frequency of recovering Alternaria spp. $\mathrm{S}\left(\chi^{2}=37.00, P<\right.$ $0.0001)$, RS $\left(\chi^{2}=15.92, P<0.0001\right)$, MI $\left(\chi^{2}=9.76, P=0.0018\right)$, and $\mathrm{R}\left(\chi^{2}=15.37, P<0.0001\right)$ sensitivity phenotypes (Table 4$)$. The probability of recovering Alternaria spp. isolates of $\mathrm{S}(P<$ $0.0001)$, RS $(P<0.0001)$, and R $(P<0.0001)$ phenotypes was significantly higher in 2017 than 2016 and was lower for MI phenotypes $(P=0.0018)$ over the same years (Table 5).

For fenbuconazole, log-linear analysis determined that collection year had a significant effect on the frequency of recovery of Alternaria spp. RS phenotypes $\left(\chi^{2}=45.86, P<0.0001\right)$ on the frequency of RS Alternaria spp. isolates collected (Table 4). The probability of collecting RS Alternaria spp. isolates was significantly higher in 2017 (Table 5) than 2016.

For flutriafol, log-linear analysis determined that collection year had a significant effect on the frequency of recovery of Alternaria spp. I ( $\left.\chi^{2}=15.11, P=0.0001\right)$ and $\mathrm{R}\left(\chi^{2}=5.63, P=0.0177\right)$ sensitivity phenotypes (Table 4$)$. The probability of recovering both I and $\mathrm{R}$ flutriafol phenotypes of Alternaria spp. isolates was significantly higher in 2017 than 2016 (Table 5).

For prothioconazole, log-linear analysis determined that collection year had a significant effect on the frequency of recovery of Alternaria spp. $\mathrm{S}\left(\chi^{2}=8.86, P=0.0029\right)$ and $\mathrm{RS}\left(\chi^{2}=7.20, P=0.0073\right)$ sensitivity phenotypes (Table 4 ). The probability of recovering Alternaria spp. isolates of $\mathrm{S}$ and RS prothioconazole phenotypes was significantly higher in 2017 than 2016 (Table 5).

For tetraconazole, log-linear analysis determined that collection year had a significant effect on the frequency of recovery of Alternaria $\operatorname{spp} . \mathrm{R}\left(\chi^{2}=4.35, P=0.0371\right)$ sensitivity phenotypes (Table 4$)$. The probability of collecting R Alternaria spp. isolates was significantly lower in 2017 (Table 5).

For pyraclostrobin, log-linear analysis determined that collection year had a significant effect on the frequency of recovery of Alternaria spp. sensitivity $\mathrm{R}\left(\chi^{2}=23.98, P<0.0001\right)$ phenotypes (Table 6). The probability of recovering R Alternaria spp. isolates was significantly higher in $2017(P<0.0001)$ (Table 6). For triphenyl tin $\mathrm{OH}$, log-linear analysis determined that collection year did not have a significant effect on the frequencies of Alternaria spp. sensitivity phenotypes (Table 6).

\section{Discussion}

Alternaria spp. with high levels of insensitivity to three classes of fungicides were recovered from leaves showing leaf spot symptoms from commercial sugarbeet production areas in the Upper Great Lakes. Management of CLS on sugarbeet relies on an integrated approach combining cultural practices, resistant varieties, and application programs using a combination of protectant (e.g., ditihiocarbamates and organo-tins) and systemic (e.g., DMIs and QoIs) fungicides (Secor et al. 2010b). Because CLS is the most important foliar disease of sugarbeet, management of ALS has historically been a minor issue and likely occurred as a consequence of foliar applications of fungicides for CLS. Therefore, the development of fungicide resistant populations of Alternaria spp. has emerged as a new problem and may be a factor, at least in part, in an increase of ALS in sugarbeet-producing areas in the Upper Great Lakes. This increased incidence and severity of ALS has been observed at levels high enough to potentially cause yield loss (Russell 1965). The current research represents a comprehensive study of the population biology related to fungicide sensitivity of the Alternaria species complex responsible for ALS on commercial sugarbeet production in the Upper Great Lakes. This study determined the sensitivity of the recovered populations of Alternaria spp. to seven different chemistries (difenoconazole, fenbuconazole, flutriafol, prothioconazole, tetraconazole, pyraclostrobin, and triphenyl tin $\mathrm{OH}$ ) in the DMI, QoI and organo-tin classes of fungicide. Subsequently, isolates of Alternaria spp. were categorized phenotypically based on mean sensitivity into S, RS, MI, I, and R and the RF was calculated for these Alternaria spp. classes to the seven fungicides. Additionally, the current study determined significant temporal shifts in Alternaria spp. fungicide sensitivity phenotypes from 2016 compared with 2017.

For the DMI fungicides, difenoconazole had the lowest mean $\mathrm{EC}_{50}$ and variability of sensitivity in both sampling years. Among all fungicides tested, the mean $\mathrm{EC}_{50}$ increased from 2016 to 2017 except in the case of tetraconazole where the mean $\mathrm{EC}_{50}$ decreased. Because this monitoring program was initiated in the last three growing seasons and is presumably attributable to the wide host range of Alternaria spp. and persistent fungicide exposure imposing a selection pressure as a consequence of CLS management, recovered pathogen populations were already predominated by resistant

Table 3. Comparison of resistance factors (RFs) in Alternaria spp. populations recovered in 2016 and 2017 from Upper Great Lakes sugarbeet production $^{\mathrm{a}}$

\begin{tabular}{|c|c|c|c|c|c|c|c|c|}
\hline \multirow[b]{2}{*}{ Year } & \multicolumn{4}{|c|}{ Pyraclostrobin } & \multicolumn{4}{|c|}{ Triphenyl tin $\mathrm{OH}$} \\
\hline & $\mathbf{R S}^{\mathbf{b}}$ & MI & I & $\mathbf{R}$ & RS & MI & I & $\mathbf{R}$ \\
\hline 2016 & 8.8 & 46.2 & 108.4 & 202.9 & 12.4 & 28.4 & 86.7 & - \\
\hline 2017 & 6.9 & 37.9 & 115.7 & 201.4 & 10.1 & 46.2 & 98.6 & 185.7 \\
\hline
\end{tabular}

${ }^{a}$ Values are presented as RFs, which were calculated as the ratio of the mean $\mathrm{EC}_{50}$ value of Alternaria spp. populations displaying decreased sensitivity compared with the mean $\mathrm{EC}_{50}$ for reference sensitive populations.

${ }^{b}$ Sensitivity of isolates to pyraclostrobin and triphenyl tin $\mathrm{OH}$ was categorized as follows: $\mathrm{RS}=$ reduced sensitivity $\left(\mathrm{EC}_{50}=1\right.$ to $\left.10 \mathrm{mg} / \mathrm{liter}\right), \mathrm{MI}=$ moderately insensitive $\left(\mathrm{EC}_{50}=10\right.$ to $\left.50 \mathrm{mg} / \mathrm{liter}\right), \mathrm{I}=$ insensitive $\left(\mathrm{EC}_{50}=\right.$ 50 to $100 \mathrm{mg} / \mathrm{liter})$, and $\mathrm{R}=$ resistant $\left(\mathrm{EC}_{50}>100 \mathrm{mg} / \mathrm{liter}\right)$.

Table 2. Comparison of resistance factors (RFs) in Alternaria spp. populations recovered in 2016 and 2017 from Upper Great Lakes sugarbeet production ${ }^{\mathrm{a}}$

\begin{tabular}{|c|c|c|c|c|c|c|c|c|c|c|c|c|c|c|c|c|c|c|c|c|}
\hline \multirow[b]{2}{*}{ Year } & \multicolumn{4}{|c|}{ Difenoconazole } & \multicolumn{4}{|c|}{ Fenbuconazole } & \multicolumn{4}{|c|}{ Flutriafol } & \multicolumn{4}{|c|}{ Prothioconazole } & \multicolumn{4}{|c|}{ Tetraconazole } \\
\hline & $\mathbf{R S}^{\mathbf{b}}$ & MI & $\mathbf{I}$ & $\mathbf{R}$ & $\mathbf{R S}$ & MI & I & $\mathbf{R}$ & RS & MI & I & $\mathbf{R}$ & $\mathbf{R S}$ & MI & I & $\mathbf{R}$ & $\mathbf{R S}$ & MI & I & $\mathbf{R}$ \\
\hline 2016 & 6.3 & 35.3 & - & - & 7.0 & 48.5 & 101.7 & 186.9 & 6.8 & 40.6 & 83.2 & 163.8 & 7.4 & 39.6 & 100.3 & 188.1 & 6.9 & 48.3 & 103.9 & 172.7 \\
\hline 2017 & 4.8 & 32.6 & 105.4 & 143.4 & 9.0 & 44.5 & 111.7 & 187.2 & 6.1 & 38.2 & 88.8 & 181.6 & 5.8 & 40.5 & 103.4 & 187.0 & 8.0 & 36.0 & 83.1 & 177.3 \\
\hline
\end{tabular}

${ }^{a}$ Values are presented as RFs, which were calculated as the ratio of the mean $\mathrm{EC}_{50}$ value of Alternaria spp. populations displaying decreased sensitivity compared with the mean $\mathrm{EC}_{50}$ for reference sensitive populations.

${ }^{\mathrm{b}}$ Sensitivity of isolates to five demethylase inhibitor fungicides (difenoconazole, fenbuconazole, flutriafol, prothioconazole, and tetraconazole) was categorized as follows: $\mathrm{RS}=$ reduced sensitivity $\left(\mathrm{EC}_{50}=1\right.$ to $\left.10 \mathrm{mg} / \mathrm{liter}\right), \mathrm{MI}=$ moderately insensitive $\left(\mathrm{EC}_{50}=10\right.$ to $\left.50 \mathrm{mg} / \mathrm{liter}\right), \mathrm{I}=$ insensitive $\left(\mathrm{EC}_{50}=50\right.$ to $\left.100 \mathrm{mg} / \mathrm{liter}\right)$ and $\mathrm{R}=$ resistant $\left(\mathrm{EC}_{50}>100 \mathrm{mg} / \mathrm{liter}\right)$. 
indi-viduals. In previous studies on Alternaria late blight (ALB) of pistachio in California, caused by Alternaria spp. in the A. alternata, A. tenuissima, and $A$. arborescens species groups, populations of $A$. alternata contained a mixture of isolates varying in DMI sensitivity (Avenot et al. 2016) and variations in $\mathrm{EC}_{50}$ distributions for the three DMIs tested in the current study were consistent with other patterns of DMI sensitivity in various fungi (Brent and Hollomon 1995). The ranges of sensitivities to tebuconazole and propiconazole were relatively wider within the A. alternata populations compared with that observed for difenoconazole (Avenot et al. 2016). Similarly, the recorded variations in A. alternata sensitivity to tebuconazole and the two other DMIs (propiconazole and difenoconazole) were within the range of the natural sensitivities of this pathogen to these fungicides (Avenot et al. 2016). The ranges of $\mathrm{EC}_{50}$ values were broad and very similar for both tebuconazole and propiconazole, and there were differences in intrinsic activity of the three DMIs tested; difenoconazole appeared more active than the two other fungicides in inhibiting A. alternata mycelial growth with a narrower distribution of $\mathrm{EC}_{50}$ values, similar to Avenot et al. (2016). In studies on A. alternata causing moldy core in apple, among the tested chemicals, polyoxin $\mathrm{B}$ and trifloxystrobin $(\mathrm{QoI})$ had the strongest effect on germination of conidia; a much higher concentration was needed to achieve the same degree of germination inhibition by azoxystrobin (QoI) or difenoconazole (DMI) (Reuveni and Sheglov 2002). Among tested chemicals, mycelial growth of the fungus was most sensitive to difenoconazole, which was effective at $0.8-12 \mathrm{mg} / \mathrm{liter}$; at higher concentrations, polyoxin $\mathrm{B}$, was effective at suppressing mycelial growth, whereas the strobilurins (trifloxystrobin and azoxystrobin) were less effective, with $\mathrm{EC}_{95}$ values of $>1,000 \mathrm{mg} / \mathrm{liter}$ (Reuveni and Sheglov 2002). Similar studies on blackspot of crucifers, caused by Alternaria spp., found three sterol biosynthesis-inhibiting fungicides; two of the triazole group (flutriafol and difenoconazole) and one of the imidazole group (prochloraz), performed equally well in reducing the mycelial growth of A. brassicae, A. brassicicola, and A. japonica (IacomiVasilescu et al. 2004). In blackspot of crucifers, isolates of Alternaria spp. were separated into four classes depending on their sensitivity to tested fungicides (iprodione, procymidone, difenoconazole, flutriafol, prochloraz, and fludioxonil): isolates were classified as sensitive, with

$\mathrm{EC}_{50}$ values ranging between 0.1 and $1 \mathrm{mg} / \mathrm{liter}$; weakly resistant, with $\mathrm{EC}_{50}$ values between 1 and $10 \mathrm{mg} / \mathrm{liter}$; intermediate resistant, with $\mathrm{EC}_{50}$ values between 10 and $100 \mathrm{mg} / \mathrm{liter}$; and highly resistant, with $\mathrm{EC}_{50}$ values above $100 \mathrm{mg} /$ liter (Iacomi-Vasilescu et al. 2004). The dicarboximide iprodione proved to be more effective than procymidone with most isolates sensitive to the phenylpyrroles fludioxonil with some $A$. brassicicola isolates highly resistant $\left(\mathrm{EC}_{50}>100 \mathrm{mg} / \mathrm{liter}\right)$ to both the dicarboximides iprodione and procymidone and phenylpyrroles (e.g., fludioxonil) (Iacomi-Vasilescu et al. 2004).

In the current study, the response to tetraconazole in Alternaria spp. related to a decrease in mean $\mathrm{EC}_{50}$ also was reflected in a decrease in the RF for both MI and I sensitivity phenotypes. Similarly, mean $\mathrm{EC}_{50}$ values among Alternaria spp. from sampled counties and provinces increased from 2016 to 2017 . Overall, RFs for the I and R phenotypes increased for four of the fungicides (difenoconazole, fenbuconazole, flutriafol, and triphenyl tin $\mathrm{OH}$ ), although the RFs for the $\mathrm{R}$ class decreased for the two fungicides (prothioconazole and pyraclostrobin). The population response to fungicides based on RFs taken together with mean sensitivities suggests a shift in the response of populations of Alternaria spp. causing ALS in the Upper

Table 6. Maximum-likelihood analysis of variance from log-linear analysis for the main effects of year on the frequency of sensitivity categories of Alternaria spp. recovered from Michigan and Ontario sugarbeet production

\begin{tabular}{|c|c|c|c|c|c|c|c|c|}
\hline \multirow[b]{2}{*}{ Sensitivity $^{\mathbf{a}}$} & \multicolumn{4}{|c|}{ Pyraclostrobin } & \multicolumn{4}{|c|}{ Triphenyl tin $\mathbf{O H}$} \\
\hline & df & $\chi^{2}$ & $P>\chi^{2 b}$ & Estimate & df & $x^{2}$ & $P>\chi^{2}$ & Estimate \\
\hline 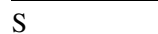 & 1 & 0.07 & 0.7964 & 0.0668 & - & - & - & - \\
\hline RS & - & - & - & - & 1 & 1.82 & 0.1772 & -0.4055 \\
\hline MI & 1 & 0.24 & 0.6227 & -0.0607 & 1 & 1.11 & 0.2918 & 0.0697 \\
\hline & - & - & - & - & - & - & - & - \\
\hline $\mathrm{R}$ & 1 & 23.98 & $<0.0001$ & 0.4686 & - & - & - & - \\
\hline \multicolumn{9}{|c|}{$\begin{array}{l}\text { Sensitivity of isolates to pyraclostrobin and triphenyl tin } \mathrm{OH} \text { was catego- } \\
\text { rized as follows: } \mathrm{S}=\text { sensitive }\left(\mathrm{EC}_{50}<1 \mathrm{mg} / \text { liter), } \mathrm{RS}=\text { reduced sensitivity }\right. \\
\left(\mathrm{EC}_{50}=1 \text { to } 10 \mathrm{mg} / \mathrm{liter}\right), \mathrm{MI}=\text { moderately insensitive }\left(\mathrm{EC}_{50}=10 \text { to } 50 \mathrm{mg} /\right. \\
\text { liter), } \mathrm{I}=\text { insensitive }\left(\mathrm{EC}_{50}=50 \text { to } 100 \mathrm{mg} / \text { liter }\right) \text {, and } \mathrm{R}=\text { resistant }\left(\mathrm{EC}_{50}>\right. \\
100 \mathrm{mg} / \text { liter). } \\
\text { b Significant if } P<0.05 .\end{array}$} \\
\hline
\end{tabular}

Table 4. Maximum-likelihood analysis of variance from log-linear analysis for the effects of year and county on the frequency of sensitivity categories of Alternaria spp. recovered from Michigan and Ontario sugarbeet production

\begin{tabular}{|c|c|c|c|c|c|c|c|c|c|c|c|c|c|c|c|}
\hline \multirow[b]{2}{*}{ Sensitivity $^{\mathbf{a}}$} & \multicolumn{3}{|c|}{ Difenoconazole } & \multicolumn{3}{|c|}{ Fenbuconazole } & \multicolumn{3}{|c|}{ Flutriafol } & \multicolumn{3}{|c|}{ Prothioconazole } & \multicolumn{3}{|c|}{ Tetraconazole } \\
\hline & df & $x^{2}$ & $P>\chi^{2 b}$ & Df & $\chi^{2}$ & $P>\chi^{2}$ & df & $x^{2}$ & $P>\chi^{2}$ & df & $x^{2}$ & $P>\chi^{2}$ & df & $x^{2}$ & $P>\chi^{2}$ \\
\hline S & 1 & 37.00 & $<0.0001$ & 1 & 0.14 & 0.7064 & 1 & 0.32 & 0.5714 & 1 & 8.86 & 0.0029 & - & - & - \\
\hline RS & 1 & 15.92 & $<0.0001$ & 1 & 45.86 & $<0.0001$ & 1 & 1.28 & 0.2585 & 1 & 7.20 & 0.0073 & 1 & 0.60 & 0.4369 \\
\hline MI & 1 & 9.76 & 0.0018 & 1 & 0.01 & 0.9042 & 1 & 3.4 & 0.0650 & 1 & 0.37 & 0.5417 & 1 & 3.12 & 0.0773 \\
\hline I & 1 & 0.08 & 0.7782 & 1 & 1.28 & 0.2571 & 1 & 15.11 & 0.0001 & 1 & 1.43 & 0.2324 & 1 & 2.70 & 0.1001 \\
\hline $\mathrm{R}$ & 1 & 15.37 & $<0.0001$ & - & - & - & 1 & 5.63 & 0.0177 & 1 & 2.31 & 0.1285 & 1 & 4.35 & 0.0371 \\
\hline
\end{tabular}

a Sensitivity of isolates to difenoconazole, fenbuconazole, flutriafol, prothioconazole, and tetraconazole was categorized as follows: $\mathrm{S}=$ sensitive $\left(\mathrm{EC}_{50}<1 \mathrm{mg} /\right.$ liter), $\mathrm{RS}=$ reduced sensitivity $\left(\mathrm{EC}_{50}=1\right.$ to $10 \mathrm{mg} /$ liter $), \mathrm{MI}=$ moderately insensitive $\left(\mathrm{EC}_{50}=10\right.$ to $\left.50 \mathrm{mg} / \mathrm{liter}\right), \mathrm{I}=$ insensitive $\left(\mathrm{EC}_{50}=50\right.$ to $\left.100 \mathrm{mg} / \mathrm{liter}\right)$, and $\mathrm{R}=$ resistant $\left(\mathrm{EC}_{50}>100 \mathrm{mg} / \mathrm{liter}\right)$.

b Significant if $P<0.05$.

Table 5. Analysis of maximum-likelihood estimates from log-linear analysis for the main effects of year on the frequency of sensitivity categories of Alternaria spp. recovered from Michigan and Ontario sugarbeet production

\begin{tabular}{|c|c|c|c|c|c|c|c|c|c|c|}
\hline \multirow[b]{2}{*}{ Sensitivity ${ }^{\mathbf{a}}$} & \multicolumn{2}{|c|}{ Difenoconazole } & \multicolumn{2}{|c|}{ Fenbuconazole } & \multicolumn{2}{|c|}{ Flutriafol } & \multicolumn{2}{|c|}{ Prothioconazole } & \multicolumn{2}{|c|}{ Tetraconazole } \\
\hline & Estimate & $P>\chi^{2 b}$ & Estimate & $P>\chi^{2}$ & Estimate & $P>\chi^{2}$ & Estimate & $P>\chi^{2}$ & Estimate & $P>\chi^{2}$ \\
\hline S & 0.9423 & $<0.0001$ & 0.1438 & 0.7064 & -0.3466 & 0.5714 & 0.6365 & 0.0029 & - & - \\
\hline RS & 0.6496 & $<0.0001$ & 1.1256 & $<0.0001$ & 0.1438 & 0.2585 & 0.4581 & 0.0073 & 0.6798 & 0.4369 \\
\hline MI & -0.6264 & 0.0018 & -0.0145 & 0.9042 & -0.2197 & 0.0650 & 0.0748 & 0.5417 & 0.2145 & 0.0773 \\
\hline I & -0.1733 & 0.7782 & 0.2695 & 0.2571 & 0.8047 & 0.0001 & 0.3031 & 0.2324 & 0.2853 & 0.1001 \\
\hline $\mathrm{R}$ & -1.1836 & $<0.0001$ & - & - & 0.2682 & 0.0177 & -0.1465 & 0.1285 & -0.1705 & 0.0371 \\
\hline
\end{tabular}

a Sensitivity of isolates to difenoconazole, fenbuconazole, flutriafol, prothioconazole, and tetraconazole was categorized as follows: $\mathrm{S}=\operatorname{sensitive~}\left(\mathrm{EC} \mathrm{C}_{50}<1 \mathrm{mg} /\right.$ liter $), \mathrm{RS}=$ reduced sensitivity $\left(\mathrm{EC}_{50}=1\right.$ to $\left.10 \mathrm{mg} / \mathrm{liter}\right), \mathrm{MI}=$ moderately insensitive $\left(\mathrm{EC}_{50}=10\right.$ to $\left.50 \mathrm{mg} / \mathrm{liter}\right), \mathrm{I}=$ insensitive $\left(\mathrm{EC}_{50}=50\right.$ to $\left.100 \mathrm{mg} / \mathrm{liter}\right)$, and $\mathrm{R}=$ resistant $\left(\mathrm{EC}_{50}>100 \mathrm{mg} / \mathrm{liter}\right)$.

b Significant if $P<0.05$. 
Great Lakes. Resistance to strobilurins has been demonstrated extensively in previous studies for several Alternaria spp., including Alternaria from sugarbeet (Avenot et al. 2008; Ma and Michailides 2004b; Malandrakis et al. 2015; Pasche et al. 2005; Rosenzweig et al. 2008a, b, 2017). Previous DNA-based and sequencing analysis revealed that all intermediate and resistant isolates contained the G143A mutation, which confers QoI resistance in Alternaria spp. (Rosenzweig et al. 2017). In the case of ALB on tomato, A. alternata isolates with dual resistance to QoIs (pyraclostrobin and azoxystrobin) were identified (Avenot et al. 2008).

For the triphenyltin class of fungicides, $C$. beticola isolates resistant to triphenyltin hydroxide have been reported in Europe and the United States (Bugbee 1995; Giannopolitis 1978; Giannopolitis and Chrysayi-Tokousbalides 1980; Karaoglanidis and Iannidis 2010; Marić et al. 1984; Secor et al. 2010a, b). In fungicide sensitivity monitoring of sugarbeet production in Greece, an increase in the frequency of tin resistance in $C$. beticola was regionally specific. Additionally, in Greece and the United States, the frequency of tin resistance in $C$. beticola was significantly reduced after a reduction or elimination of tin fungicide applications or fungicide use history (Giannopolitis 1978; Ioannidis 1994; Secor et al. 2010b). Restricted tin fungicide use allowed the reduction, later in the season, of the resistant strains selected for by multiple tin applications, since in the absence of tin fungicides the resistant strains do not compete well with the sensitive strains (Giannopolitis and Chrysayi-Tokousbalides 1980). To our knowledge, the current study is the first report of tin tolerance in a fungus other than $C$. beticola, with isolates collected in 2017 that had $\mathrm{EC}_{50}$ values $>100 \mathrm{mg} /$ liter (classified as resistant).

Sugarbeet leaf spot disease management issues related to persistent applications of fungicides for CLS likely has led to the development of insensitivity in Alternaria spp. to the QoI, DMI, and triphenyltin hydroxide fungicides. This fungicide insensitivity coincided with an increase incidence and severity of ALS observed at levels that cause yield loss as a result of defoliation and reduction in photosynthetic capacity. These results indicate that few if any of these currently used fungicides for leaf spot disease management in sugarbeet may be effective at controlling many Alternaria isolates found in the region. Moreover, individual isolates were recovered with multiple resistance to two or even all three of the fungicide classes. Determining the efficacy of currently labeled fungicides for CLS management in sugarbeet for use in ALS disease management, coupled with fungicide resistance monitoring, is essential for developing use recommendations for the region. This current study indicates the potential for Alternaria spp. populations that have multiple resistance and predisposition to reduced sensitivity to three of the major fungicides labeled for management of leaf spot on sugarbeet. Results are similar to those for other crops. For example, the distribution of sensitivities to DMI fungicides among isolates in A. alternata populations causing $\mathrm{ALB}$ in California was continuous, ranging from sensitive phenotypes to phenotypes with reduced sensitivity to tebuconazole, propiconazole, and, to a lesser extent, difenoconazole (Avenot et al. 2016). Cross-resistance among these three DMIs also was found but varied owing to differences in sensitivity patterns among fungal isolates and the relative intrinsic activity of DMIs (Gubler et al. 1996; Leroux and Walker 2011). Cross-resistance among fungicides within the DMI class has been reported in other fungi as well (Karaoglanidis and Thanassoulopoulos 2003; Köller et al. 1997; Thomas et al. 2012). Cross-resistance was observed among the DMI fungicides tebuconazole, difenoconazole, and propiconazole in A. alternata from pistachio. This is common among fungicides belonging to the same chemical class because they share a similar mode of action, and this has implications for disease management using DMIs (Avenot et al. 2016). The higher intrinsic activity shown by difenoconazole suggests that in the event of poor control with one DMI (e.g., tebuconazole), the use of this fungicide in the field could provide adequate control of ALB (Avenot et al. 2016), and the current study indicates that a similar situation may be true for ALS on sugarbeet.

Continued monitoring of populations of Alternaria spp. causing ALS in the Upper Great Lakes is required to determine the sensitivity to available fungicides and determine baseline sensitivity to new chemistries. Toward determining baseline sensitivity to existing fungicides, the need to explore sources of nonfungicide exposed isolates to have a better estimate of the shifts in sensitivity is essential. Potentially a source of baseline isolates could be from organic table beet production fields. The development of DNA-based approaches targeting mutations responsible for fungicide resistance will aid in the early detection of resistant individuals. Additionally, studies on the competitive fitness of individuals resistant to tin or resistant to multiple fungicide modes of action and their impact on disease management are needed. An integrated approach, combining sensitivity monitoring with fungicide efficacy related to pathogen biology, is essential to developing fungicide resistant management recommendations. For example, because these results indicate a significant potential for cross-resistance between related DMI fungicides, it is recommended to not use DMIs successively, limit the total number of applications of DMIs in a season, and alternate or combine fungicide chemistries with different modes of action. In addition, the development of fungicide resistance management recommendations for Alternaria spp. should incorporate epidemiological models that focus on application tactics, fungicide dynamics, effects of fungicide, and dose response. Epidemiological models of application tactics should compare the efficacy of mixtures to alternations (e.g., highlow versus low-high). Moreover, the resistant management models should integrate previously validated leaf spot disease prediction models (Bolton et al. 2012; Kaiser et al. 2010; Khan et al. 2007; Windels et al. 1998) adapted over successive growing seasons. Such models would need to be adapted for ALS, since they were developed for leaf spot from $C$. beticola, which has higher optimum temperatures for disease development, between 25 and $35^{\circ} \mathrm{C}$ (Franc 2010) and disease development occurring up to $40^{\circ} \mathrm{C}$ (Jacobsen and Franc 2009), whereas ALS has lower optimum temperatures. The effects of fungicide sequence and timing should be evaluated for fungicides considered high risk (e.g., pyraclostrobin), moderate risk (e.g., difenaconazole), and low risk (e.g., mancozeb) for resistance development. In addition to development of resistance management recommendations for use of currently available fungicides labeled for leaf spot of sugarbeet, the use of ALS resistant cultivars can potentially enhance and prolong fungicide efficacy. However, the availability of resistant cultivars is not known, as there has been little testing for response to this disease in beet. The development of new chemistries and evaluating efficacy and sensitivity of Alternaria spp. populations to available chemistries not currently labeled for leaf spot of sugarbeet will be essential for potential fungicide programs going forward.

\section{Acknowledgments}

The authors thank all of the agriculturists from Michigan Sugar Company who assisted in collection of samples.

\section{Literature Cited}

Abbas, H. M., Farooq, M. A., Atta, S., Haider, M. S., Subhani, M. N., and Ali, S. 2014. Evaluation of different sugar beet varieties against Fusarium oxysporum f. sp. betae and Alternaria alternata. Pak. J. Phytopathol. 26:117-119.

Avenot, H., Morgan, D., and Michailides, T. 2008. Resistance to pyraclostrobin, boscalid and multiple resistance to Pristine ${ }^{\circledR}$ (pyraclostrobin+ boscalid) fungicide in Alternaria alternata causing alternaria late blight of pistachios in California. Plant Pathol. 57:135-140.

Avenot, H. F., and Michailides, T. J. 2007. Resistance to boscalid fungicide in Alternaria alternata isolates from pistachio in California. Plant Dis. 91: 1345-1350.

Avenot, H. F., Solorio, C., Morgan, D. P., and Michailides, T. J. 2016. Sensitivity and cross-resistance patterns to demethylation-inhibiting fungicides in California populations of Alternaria alternata pathogenic on pistachio. Crop Prot. 88:72-78.

Avila-Adame, C., Olaya, G., and Köller, W. 2003. Characterization of Colletotrichum graminicola isolates resistant to strobilurin-related QoI fungicides. Plant Dis. 87:1426-1432.

Bartlett, D. W., Clough, J. M., Godwin, J. R., Hall, A. A., Hamer, M., and ParrDobrzanski, B. 2002. The strobilurin fungicides. Pest Manag. Sci. 58:649-662.

Bauske, M. J., Mallik, I., Yellareddygari, S. K. R., and Gudmestad, N. C. 2018 Spatial and temporal distribution of mutations conferring QoI and SDH resistance in Alternaria solani across the United States. Plant Dis. 102 349-358.

Bolton, M. D., Rivera-Varas, V., del Río Mendoza, L. E., Khan, M. F., and Secor, G. A. 2012. Efficacy of variable tetraconazole rates against Cercospora beticola 
isolates with differing in vitro sensitivities to DMI fungicides. Plant Dis. 96: 1749-1756.

Brent, K. J., and Hollomon, D. W. 1995. Fungicide Resistance in Crop Pathogens: How Can It Be Managed? Groupement International des Associations Nationales de Fabricants de Produits Agrochimiques, Brussels, Belgium.

Bugbee, W. 1995. Cercospora beticola tolerant to triphenyltin hydroxide. J. Sugar Beet Res. 32:167-174

Chin, K. M., Chavaillaz, D., Kaesbohrer, M., Staub, T., and Felsenstein, F. G. 2001. Characterizing resistance risk of Erysiphe graminis f. sp. tritici to strobilurins. Crop Prot. 20:87-96.

Cooley, R., and Caten, C. 1993. Molecular analysis of the Septoria nodorum $\beta$-tubulin gene and characterization of a benomyl-resistance mutation. Mol. Gen. Genet. 237:58-64.

Davidse, L., and Flach, W. 1977. Differential binding of methyl benzimidazol-2-yl carbamate to fungal tubulin as a mechanism of resistance to this antimitotic agent in mutant strains of Aspergillus nidulans. J. Cell Biol. 72:174-193.

Dewdney, M., and Vega, B. 2012. Status of resistance of Alternaria to fungicides in tangerine production. Citrus Ind. 93:14-17.

Förster, H., Kanetis, L., and Adaskaveg, J. E. 2004. Spiral gradient dilution, a rapid method for determining growth responses and 50\% effective concentration values in fungus-fungicide interactions. Phytopathology 94:163-170.

Franc, G. 2010. Ecology and epidemiology of Cercospora beticola. Pages 7-19 in: Cercospora Leaf Spot of Sugar Beet and Related Species. R. T. Lartey, J. J. Weiland, L. Panella, P. W. Crous, and C. E. Windels, eds. American Phytopathological Society, St. Paul, MN.

Franc, G. D. 2009. Alternaria leaf spot. Pages 12-13 in: Compendium of Beet Diseases and Pests. R. M. Haveson, L. E. Hanson, and G. L. Heil, eds. American Phytopathological Society, St. Paul, MN.

Giannopolitis, C. 1978. Occurrence of strains of Cercospora beticola resistant to triphenyltin fungicides in Greece. Plant Dis. Rep. 62:205-208.

Giannopolitis, C., and Chrysayi-Tokousbalides, M. 1980. Biology of triphenyltin-resistant strains of Cercospora beticola from sugar beet. Plant Dis. 64:940-942.

Grasso, V., Palermo, S., Sierotzki, H., Garibaldi, A., and Gisi, U. 2006. Cytochrome b gene structure and consequences for resistance to Qo inhibitor fungicides in plant pathogens. Pest Manag. Sci. 62:465-472.

Gubler, W., Ypema, H., Ouimette, D., and Bettiga, L. 1996. Occurrence of resistance in Uncinula necator to triadimefon, myclobutanil, and fenarimol in California grapevines. Plant Dis. 80:902-909.

Hasija, S. 1970. Physiological studies of Alternaria citri and A. tenuis. Mycologia 62:289-295.

Iacomi-Vasilescu, B., Avenot, H., Bataillé-Simoneau, N., Laurent, E., Guénard, M., and Simoneau, P. 2004. In vitro fungicide sensitivity of Alternaria species pathogenic to crucifers and identification of Alternaria brassicicola field isolates highly resistant to both dicarboximides and phenylpyrroles. Crop Prot. 23:481-488.

Ioannidis, P. 1994. Fungicides chemicals and techniques for controlling Cercospora beticola Sacc. in Greece Pages 139-151 in: Proceedings of Mediterranean Committee Meeting of IIRB, Thessaloniki, Greece.

Ishii, H., Fraaije, B. A., Sugiyama, T., Noguchi, K., Nishimura, K., Takeda, T., Amano, T., and Hollomon, D. W. 2001. Occurrence and molecular characterization of strobilurin resistance in cucumber powdery mildew and downy mildew. Phytopathology 91:1166-1171.

Jacobsen, B., and Franc, G. 2009. Cercospora leaf spot. Pages 7-9 in: Compendium of Beet Diseases and Pests. R. M. Haveson, L. E. Hanson, and G. L. Hein, eds. American Phytopathological Society, St. Paul, MN.

Jung, M., Wilder, I., and Oakley, B. 1992. Amino acid alterations in the benA ( $\beta$-tubulin) gene of Aspergillus nidulans that confer benomyl resistance. Cell Motil. Cytoskeleton 22:170-174.

Kaiser, U., Kluth, C., and Marlander, B. 2010. Variety-specific epidemiology of Cercospora beticola Sacc. and consequences for threshold-based timing of fungicide application in sugar beet. J. Phytopathol. 158:296-306.

Karaoglanidis, G., and Iannidis, P. 2010. Fungicide resistance of Cercospora beticola in Europe. Pages 189-211 in: Cercospora Leaf Spot of Sugar Beet and Related Species. R. T. Lartey, J. J. Weiland, L. Panella, P. W. Crous, and C. E. Windels, eds. American Phytopathological Society, St. Paul, MN.

Karaoglanidis, G., and Thanassoulopoulos, C. 2003. Cross-resistance patterns among sterol biosynthesis inhibiting fungicides (SBIs) in Cercospora beticola. Eur. J. Plant Pathol. 109:929-934.

Khan, J., Del Rio, L., Nelson, R., and Khan, M. 2007. Improving the Cercospora leaf spot management model for sugar beet in Minnesota and North Dakota. Plant Dis. 91:1105-1108.

Kirk, W., Hanson, L., Franc, G., Stump, W., Gachango, E., Clark, G., and Stewart, J. 2012. First report of strobilurin resistance in Cercospora beticola in sugarbeet Beta vulgaris in Michigan and Nebraska, USA. New Dis. Rep. 26:3.

Köller, W., Wilcox, W., Barnard, J., Jones, A., and Braun, P. 1997. Detection and quantification of resistance of Venturia inaequalis populations to sterol demethylation inhibitors. Phytopathology 87:184-190.

Küng Färber, R., Chin, K. M., and Leadbitter, N. 2002. Sensitivity of Venturia inaequalis to trifloxystrobin. Pest Manag. Sci. 58:261-267.

Leroux, P., and Walker, A. S. 2011. Multiple mechanisms account for resistance to sterol $14 \alpha$-demethylation inhibitors in field isolates of Mycosphaerella graminicola. Pest Manag. Sci. 67:44-59.
Ma, Z., Felts, D., and Michailides, T. J. 2003. Resistance to azoxystrobin in Alternaria isolates from pistachio in California. Pestic. Biochem. Physiol. 77: 66-74.

Ma, Z., and Michailides, T. 2004a. An allele-specific PCR assay for detecting azoxystrobin-resistant Alternaria isolates from pistachio in California. J. Phytopathol. 152:118-121.

Ma, Z., and Michailides, T. J. 2004b. A real-time PCR assay for the detection of azoxystrobin-resistant Alternaria populations from pistachio orchards in California. Crop Prot. 23:1259-1263.

Malandrakis, A. A., Apostolidou, Z. A., Markoglou, A., and Flouri, F. 2015. Fitness and cross-resistance of Alternaria alternata field isolates with specific or multiple resistance to single site inhibitors and mancozeb. Eur. J. Plant Pathol. 142:489-499.

Marić, A., Maširević, S., and Jerković, Z. 1984. Increase in resistance of Cercospora beticola to benomyl and first occurrence of strains tolerant of fentin acetate in Vojvodini. Zast. Bilja 35:207-215.

McFarlane, J., Bardin, R., and Snyder, W. C. 1954. An Alternaria leaf spot of the sugar beet. Proc. Am. Soc. Sugarbeet Technologists 8:241-245.

Miller, P. M. 1955. V-8 juice agar as a general-purpose medium for fungal and bacteria. Phytopathology 45:461-462.

Neergaard, P. 1945. Danish Species of Alternaria and Stemphylium. Oxford University Press, London, UK.

Olaya, G., Cleere, S., Stanger, C., Burbidge, J., Hall, A., and Windass, J. 2003. A novel potential target site of QoI fungicide resistance mechanism in Pythium aphanidermatum. Phytopathology 93:S67.

Özgönen, H., and Kılıç, H. 2009. Determination of fungal diseases and diseases prevalence in sugar beet growing areas in Isparta provinces. Ziraat Fak Dergisi-Suleyman Demirel Univ. 4:16-22.

Pasche, J. S., Piche, L. M., and Gudmestad, N. C. 2005. Effect of the F129L mutation in Alternaria solani on fungicides affecting mitochondrial respiration. Plant Dis. 89:269-278.

Reijo, R. A., Cooper, E. M., Beagle, G. J., and Huffaker, T. C. 1994 Systematic mutational analysis of the yeast beta-tubulin gene. Mol. Biol. Cell 5:29-43.

Reuveni, M., and Sheglov, D. 2002. Effects of azoxystrobin, difenoconazole, polyoxin B (polar) and trifloxystrobin on germination and growth of Alternaria alternata and decay in red delicious apple fruit. Crop Prot. 21 951-955.

Rosenzweig, N., Atallah, Z., Olaya, G., and Stevenson, W. 2008a. Evaluation of QoI fungicide application strategies for managing fungicide resistance and potato early blight epidemics in Wisconsin. Plant Dis. 92:561-568.

Rosenzweig, N., Hanson, L., Clark, G., Franc, G., Stump, W., Jiang, Q., Stewart, J., and Kirk, W. 2015. Use of PCR-RFLP analysis to monitor fungicide resistance in Cercospora beticola populations from sugarbeet (Beta vulgaris) in Michigan, United States. Plant Dis. 99:355-362.

Rosenzweig, N., Hanson, L., Pratt, D., Stewart, J., and Somohano, P. 2017. First report of QoI resistance in Alternaria spp. infecting sugar beet (Beta vulgaris). New Dis. Rep. 36:5.

Rosenzweig, N., Olaya, G., Atallah, Z., Cleere, S., Stanger, C., and Stevenson, W 2008b. Monitoring and tracking changes in sensitivity to azoxystrobin fungicide in Alternaria solani in Wisconsin. Plant Dis. 92:555-560.

Rotem, J. 1994. The Genus Alternaria: Biology, Epidemiology, and Pathogenicity. American Phytopathological Society, St. Paul, MN.

Russell, G. E. 1965. The control of Alternaria species on leaves of sugar beet infected with yellowing viruses. Ann. Appl. Biol. 56:111-118.

Secor, G., Rivera, V., Khan, M., and Gudmestad, N. 2010a. Monitoring fungicide sensitivity of Cercospora beticola of sugar beet for disease management decisions. Plant Dis. 94:1272-1282.

Secor, G., Rivera-Varas, V., Gudmestad, N., and Weiland, J. 2010b. Sensitivity of Cercospora beticola in the Red River Valley of North Dakota and Minnesota. Pages XX-XX in: Cercospora Leaf Spot of Sugar Beet and Related Species. R. T. Lartey, J. J. Weiland, L. Panella, P. W. Crous, and C. E. Windels, eds. American Phytopathological Society, St. Paul, MN.

Simmons, E. 2007. Alternaria: An Identification Manual: Fully Illustrated and With Catalogue Raissone 1796-2007. CBS Fungal Biodiversity Centre, Utrecht, The Netherlands.

Thomas, A., Langston, D., Jr., and Stevenson, K. 2012. Baseline sensitivity and cross-resistance to succinate-dehydrogenase-inhibiting and demethylationinhibiting fungicides in Didymella bryoniae. Plant Dis. 96:979-984.

Torres-Londoño, G. A., Hausbeck, M., and Hao, J. 2016. ECX: An R package for studying sensitivity of antimicrobial substances using spiral plating technology. Plant Health Prog. 17:188-194.

Trueman, C., Hanson, L., Rosenzweig, N., Jiang, Q., and Kirk, W. 2013. Firs report of QoI insensitive Cercospora beticola on sugar beet in Ontario, Canada. Plant Dis. 97:1255.

Trueman, C., Hanson, L., Somohano, P., and Rosenzweig, N. 2017. First report of DMI-insensitive Cercospora beticola on sugar beet in Ontario, Canada. New Dis. Rep. 36:20.

Windels, C., Lamey, H., Hilde, D., Widner, J., and Knudsen, T. 1998. A Cerospora leaf spot model for sugar beet: In practice by an industry. Plant Dis. 82:716-726.

Woudenberg, J., Groenewald, J., Binder, M., and Crous, P. 2013. Alternaria redefined. Stud. Mycol. 75:171-212. 